\title{
Comparison of Serum Growth Hormone Levels After Bovril and Insulin Stimulation
}

\author{
D. B. GRANT, DOREEN JACKSON, S. RAITI, and BARBARA E. CLAYTON \\ From The Hospital for Sick Children, and Institute of Child Health, London
}

\begin{abstract}
Grant, D. B., Jackson, D., Raiti, S., and Clayton, B. E. (1970). Archives of Disease in Childhood, 45, 544. Comparison of serum growth hormone levels after Bovril and insulin stimulation. Serum growth hormone (HGH) levels were estimated in 60 children during Bovril and intravenous insulin tests. The results of the two tests correlated well. 37 subjects had $\mathrm{HGH}$ levels over $10 \mu \mathrm{IU} / \mathrm{ml}$. during both tests, and 18 subjects failed to respond to either test. 4 subjects showed minor discrepancies between the results of the two tests, and one child with the emotional deprivation syndrome had a good response to insulin but no significant rise in serum HGH during her first Bovril test. It was concluded that the two tests were of comparable value in the assessment of children with suspected growth hormone deficiency, and that the Bovril test had the advantages of being safe and avoiding intravenous administration.
\end{abstract}

We have previously reported that administration of Bovril to women and children is commonly followed by a rise in serum growth hormone (HGH), and have suggested that Bovril stimulation provides a safe method for investigating children with suspected growth hormone deficiency (Jackson, Grant, and Clayton, 1968). This paper describes the results of Bovril tests in a further 60 abnormally small children with a variety of disorders and compares them with the serum HGH results obtained in the same subjects after intravenous injection of insulin.

\section{Subjects and Methods}

Subjects. 40 boys and 20 girls between the ages of 3 and $18 \frac{1}{2}$ years were studied. The heights of all the subjects were below the 3rd centile for age (Tanner, Whitehouse, and Takaishi, 1966). In 22 cases, short stature was associated with recognized clinical conditions (Table). The remaining 38 children, many of whom could not be classified with certainty, had growth rates between 1.3 and $6.7 \mathrm{~cm}$./year, showed up to 7 years' delay in bone maturation at the wrist and hand (Tanner, Whitehouse, and Healy, 1962), and had normal plasma levels of protein-bound iodine.

Methods. Bovril and insulin tests were carried out after an overnight fast, with the subjects resting on their beds. All the tests began between 9.30 and

Received 26 January 1970.
TABLE

Diagnosis in 22 Children with Short Stature Associated with Recognized Clinical Conditions

\begin{tabular}{l|c}
\hline \multicolumn{1}{c|}{ Diagnosis } & $\begin{array}{c}\text { No. of } \\
\text { Patients }\end{array}$ \\
\hline Low birthweight for gestational age, with or without & \\
$\quad$ asymmetry & 8 \\
Turner's syndrome & 2 \\
Generalized bone anomaly & 1 \\
Emotional deprivation syndrome & 1 \\
Laurence-Moon-Biedl syndrome & 8 \\
\hline
\end{tabular}

10.30 a.m. After collection of a capillary blood sample by finger-prick, Bovrilћ (20 g./1.5 m.2) was given by mouth in approximately $160 \mathrm{ml}$. warm water and 5 further capillary specimens were collected at 30-minute intervals. On another occasion, blood samples were obtained from an indwelling intravenous needle immediately before and $30,45,60,90$, and 120 minutes after an intravenous injection of insulin ( $0 \cdot 1 \mathrm{U} / \mathrm{kg}$.)

Serum $\mathrm{HGH}$ levels were estimated on all specimens $N$ using a double-antibody radioimmunoassay method (Jackson et al., 1968). Medical Research Council w Standard A and 1st International Reference Preparation $\bar{\sigma}$ for Immunoassay (IRP) were used as assay standards. Results have been expressed in terms of the IRP, using a factor of $1 \cdot 2$ to convert $\mathrm{m} \mu \mathrm{g}$. Standard A to $\mu$ IU IRP. ? HGH estimations were carried out over a period of 20

\footnotetext{
${ }^{\star}$ Bovril Ltd., Sunleigh Road, Alperton, Middlesex.
} 
months. During this period a control specimen of serum included in 32 assays gave a mean value of $5 \mu \mathrm{IU} / \mathrm{ml}$. with a standard deviation of $1 \cdot 1 \mu \mathrm{IU} / \mathrm{ml}$. Other statistical parameters of the method showed no change from those previously described (Jackson et al., 1968).

Some of the patients had been treated with $\mathrm{HGH}$ several months before the Bovril and insulin tests. Serum specimens from these patients gave negative results when tested for anti-HGH antibodies, using electrophoresis in acrylamide gel to separate free and bound ${ }^{125}$ I HGH (Fitschen, 1964). Recovery of HGH from these specimens, and results obtained when they were assayed at several dilutions, also indicated that previous treatment with $\mathrm{HGH}$ did not interfere with the immunoassay results in these subjects.

Previous studies have indicated that hypopituitary subjects have peak serum $\mathrm{HGH}$ levels of less than $10 \mu \mathrm{IU} / \mathrm{ml}$. after Bovril (Jackson et al., 1968). Accordingly, a serum $\mathrm{HGH}$ level over $10 \mu \mathrm{IU} / \mathrm{ml}$., which is roughly equivalent to $5 \mathrm{~m} \mu \mathrm{g}$. Wilhelmi-type $\mathrm{HGH} / \mathrm{ml}$., has been taken as a normal response to Bovril or insulin.

Blood glucose was estimated on samples from the insulin tests, using a glucose-oxidase method adapted for the autoanalyser (Trinder, 1969). A fall in blood glucose of more than $50 \%$ after insulin was considered a satisfactory stimulus for growth hormone release.

\section{Results}

The peak serum HGH values obtained during the 60 paired Bovril and insulin tests are shown in the Fig. Obvious discrepancy between the results of the two tests was found in only one child. HGH values over $10 \mu \mathrm{IU} / \mathrm{ml}$. were obtained in 39 patients during the Bovril tests. In 2 of these subjects the highest HGH levels were found in the fasting specimens, but in the remainder the peak values occurred 30-150 minutes after Bovril. 40 subjects had serum $\mathrm{HGH}$ values over $10 \mu \mathrm{IU} / \mathrm{ml}$. during their insulin tests. Adequate hypoglycaemia was obtained in 19 of the 20 subjects whose HGH levels never rose above $10 \mu \mathrm{IU} / \mathrm{ml}$. after insulin. 37 subjects showed HGH levels over $10 \mu \mathrm{IU} / \mathrm{ml}$. during both tests (Fig.). Though the results for the two tests showed good correlation in these subjects, the serum $\mathrm{HGH}$ values after insulin were generally higher than those obtained after Bovril.

In 18 patients the serum $\mathrm{HGH}$ levels were less than $10 \mu \mathrm{IU} / \mathrm{ml}$. throughout both tests. 8 of these subjects had a history of surgery for craniopharyngioma and a further 3 had shown obvious acceleration of growth during earlier treatment with HGH. Isolated HGH deficiency was considered a likely diagnosis in a further 6 patients who had growth rates between $2.3 \mathrm{~cm}$./year and $4.6 \mathrm{~cm}$. $/$ year, with considerable delay in bone maturation. One patient who failed to respond to Bovril and insulin had Turner's syndrome (XX/XO mosaic) with a normal bone age, and was almost certainly not growth hormone deficient.

The one patient in whom there was an obvious discrepancy between the results of the two tests was a girl with features of the emotional deprivation syndrome. She failed to respond to Bovril 2 days after admission to hospital but had a peak HGH level of $23.9 \mu \mathrm{IU} / \mathrm{ml}$. during an insulin test 4 days later. However, a serum HGH level of $23.7 \mu \mathrm{IU} /$ ml. was obtained during a second Bovril test performed 3 weeks after admission.

Minor discrepancies, within the limits of experimental error, were found between the results of the paired tests in 4 subjects. Two boys with growth rates of $2.8 \mathrm{~cm}$./year and $3.6 \mathrm{~cm}$./year, and 3.2 and

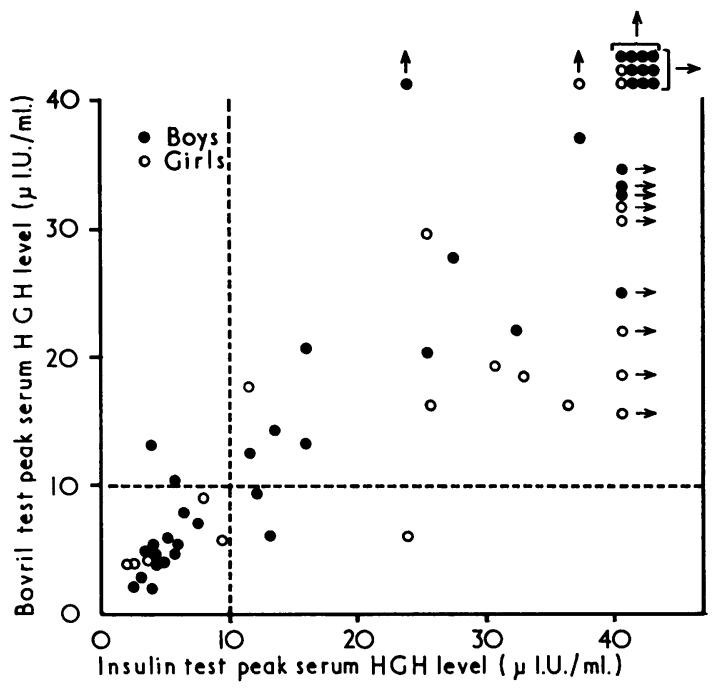

FIG.- $A$ comparison between the peak serum $H G H$ levels obtained during paired Bovril and insulin tests in 60 abnormally short children.

4.8 years' delay in bone maturation had serum HGH levels of less than $10 \mu \mathrm{IU} / \mathrm{ml}$. after insulin but values of $10.8 \mu \mathrm{IU} / \mathrm{ml}$. and $13.4 \mu \mathrm{IU} / \mathrm{ml}$. after Bovril. One boy who was growing at a rate of $5.9 \mathrm{~cm}$./year had peak $\mathrm{HGH}$ values of $12.0 \mu \mathrm{IU} /$ $\mathrm{ml}$. after insulin and $9.6 \mu \mathrm{IU} / \mathrm{ml}$. after Bovril, and another boy with a growth rate of $5.1 \mathrm{~cm}$./year had peak HGH levels of $13 \cdot 1 \mu \mathrm{IU} / \mathrm{ml}$. after insulin and $5.9 \mu \mathrm{IU} / \mathrm{ml}$. after Bovril.

\section{Discussion}

Several tests for assessing patients with suspected HGH deficiency have been described. Insulininduced hypoglycaemia (Roth et al., 1963), and 
arginine infusion (Knopf et al., 1965) are probably the two most commonly used procedures, but injection of pyrogen (Frohman, Aceto, and MacGillivary, 1967), vasopressin (Gagliardino, Bailey, and Martin, 1967), glucagon (Mitchell, Byrne, and Silver, 1969) or tolbutamide (Hunter and Greenwood, 1964), and administration of glucose by mouth (Hunter et al., 1967) have all been advocated as suitable test procedures. The above results, together with our earlier findings in 63 children (Jackson et al., 1968), indicate that the Bovril test is of value in the investigation of children with possible HGH deficiency, and that it compares favourably with the more commonly used insulin test. In particular, it is safe and avoids intravenous administration.

Though many of our subjects showed a conspicuous rise in serum HGH during both stimulation tests, a few had borderline responses, and the results could not be interpreted with certainty. Similar difficulties have been encountered by other workers, and it has been suggested that these blunted responses may indicate partial HGH deficiency (Youlton, Kaplan, and Grumbach, 1969). Repeat studies in our patients, together with assessment of their response to HGH therapy, may provide further evidence for this concept.

Several workers have reported discrepancies between the results of arginine and insulin stimulation tests (Parker, Hammond, and Daughaday, 1967; Raiti, Davis, and Blizzard, 1967; Youlton et al., 1969). Only one subject in the present study showed very discrepant responses to Bovril and insulin. It is possible that the patient with Turner's syndrome in the present series who failed to respond to either test might have shown a normal $\mathrm{HGH}$ response to another stimulus, such as arginine infusion.

Capillary blood samples were used in the Bovril tests described above, and it is possible that the stress of repeated finger-pricks, together with the diurnal changes in serum HGH which are common in children (Hunter and Rigal, 1966; Frohman et al., 1967), may have contributed to a rise in HGH during some of the tests. We have not carried out a systematic study in children to investigate this possibility but limited studies in a small number of children, together with results obtained in women (Jackson et al., 1968; Buckler, 1969), strongly suggest that the above results were specifically related to the administration of Bovril. The general similarity between the results after Bovril and insulin provides further indirect evidence to support this view. We are still uncertain as to how Bovril, a complex mixture of substances, stimulates $\mathrm{HGH}$ release, and investigations are in progress to try and identify the active ingredient.

We wish to thank Dr. G. H. Newns for allowing us to investigate his patients, Professor J. M. Tanner for providing growth data on many of the patients, and the Medical Research Council for financial support.

\section{REFERENCES}

Buckler, J. M. (1969). The effect of age, sex and exercise on the secretion of growth hormone. Clinical Science, 37, 765.

Fitschen, W. (1964). A quantitative study of antigen-antibody combination during disc electrophoresis in acrylamide gel using iodine-131 labelled human growth hormone. Immunology, 7, 307.

Frohman, L. A., Aceto, T., Jr., and MacGillivary, M. H. (1967) Studies of growth hormone secretion in children: normal, hypopituitary and constitutionally delayed. Fournal of Clinical Endocrinology, 27, 1409.

Gagliardino, J., Bailey, J. D., and Martin, J. M. (1967). Effects of vasopressin on serum-levels of human growth hormone. Lancet, 1, 1357.

Hunter, W. M., and Greenwood, F. C. (1964) Studies on the secretion of human-pituitary-growth hormone. British Medical fournal, $1,804$.

, and Rigal, W. M. (1966). The diurnal pattern of plasma growth hormone concentration in children and adolescents. Fournal of Endocrinology, 34, 147.

- Wolfsdorf, J., Farquhar, J. W., and Rigal, W. M. (1967) Screening tests for growth-hormone deficiency in dwarfism. Lancet, 2, 1271.

Jackson, D., Grant, D. B., and Clayton, B. E. (1968). A simple ora test of growth-hormone secretion in children. Lancet, 2, 373.

Knopf, R. F., Conn, J. W., Fajans, S. S., Floyd, J. C., Guntsche, E. M., and Rull, J. A. (1965). Plasma growth hormone response to intravenous administration of amino acids. Fournal of Clinical Endocrinology, 25, 1140.

Mitchell, M. L., Byrne, M. J., and Silver, J. (1969). Growthhormone release by glucagon. Lancet, 1, 289.

Parker, M. L., Hammond, J. M., and Daughaday, W. H. (1967). The arginine provocative test: an aid in the diagnosis of hyposomatotropism. Fournal of Clinical Endocrinology, 27, 1129.

Raiti, S., Davis, W. T., and Blizzard, R. M. (1967). A comparison of the effects of insulin hypoglycaemia and arginine infusion on release of human growth hormone. Lancet, $2,1182$.

Roth, J., Glick, S. M., Yalow, R. S., and Berson, S. A. (1963). Hypoglycemia: a potent stimulus to secretion of growth hormone. Science, 140, 987.

Tanner, J. M., Whitehouse, R. H., and Healy, M. J. R. (1962). A New System for Estimating Skeletal Maturity from the Hand and Wrist, with Standards Derived from a Study of 2,600 Healthy British Children. Centre International de l'Enfance. Paris.

- Whitehouse, R. H., and Takaishi, M. (1966). Standards from birth to maturity for height, weight, height velocity, and weight velocity: British children, 1965. I. Archives of Disease in Childhood, 41, 454.

Trinder, P. (1969). Determination of blood glucose using an oxidase-peroxidase system with a non-carcinogenic chromogen. fournal of Clinical Pathology, 22, 158.

Youlton, R., Kaplan, S. L., and Grumbach, M. M. (1969). Growth and growth hormone. IV. Limitations of the growth hormone response to insulin and arginine and of the immunoreactive insulin response to arginine in the assessment of growth hormone deficiency in children. Pediatrics, 43, 989.

Correspondence to Dr. B. E. Clayton, Department of Chemical Pathology, The Hospital for Sick Children, Great Ormond Street, London W.C.1. 